\title{
Mixed arbuscular mycorrhizae from the Triassic of Antarctica
}

Carlie J. Phipps

Thomas N. Taylor ${ }^{1}$

Department of Botany and Natural History Museum, University of Kansas, Lawrence, Kansas 66045

\begin{abstract}
Arbuscular mycorrhizae are the most ubiquitous of mycorrhizal fungi, that have formed mutualistic relationships with virtually almost all major groups of vascular plants. Five genera of arbuscular endomycorrhizal fungi are currently delineated, but fossil arbuscular mycorrhizae have been allied with only two, Glomus and Sclerocystis. A Triassic arbuscular mycorrhiza described inhabiting the roots of $A n$ tarcticycas was originally allied with Glomus. It is now known to be a mixed colony comprised of fungi attributable to the suborders Glomineae and Gigasporineae of the Glomales, described as two new species. The fossil Gigasporinean mycorrhiza is characterized by irregularly swollen intercellular and intracellular hyphae that are coiled extensively within the cells. Arbuscules have thick trunks and narrow branches. In the Glominean form, hyphal diameter is more uniform, with coiling rarely present. Arbuscules have thin trunks and fine branches. Vesicles may be lateral or terminal. Spores are not present; therefore, the probability of more than one species of each suborder being represented cannot be conclusively demonstrated. This provides the first fossil representative of the Gigasporineae and supports current rDNA estimates of the age of the lineage. Moreover, it is the first reported instance of a mixed colony of arbuscular endomycorrhizae in the fossil record.
\end{abstract}

Key Words: Antarcticycas, arbuscules, fossil fungi, Gigasporineae, Glomales, Glomineae

\section{INTRODUCTION}

Fungi have played a major role in the establishment and maintanance of ecosystems, and as a result have developed mutualistic relationships with many different organisms. Plants and fungi have had a particularly long-lived relationship in the form of mycorrhi-

Accepted for publication May 8, 1996.

${ }^{1}$ Author for correspondence, email address: ttaylor@falcon.cc. ukans.edu. zae. Mycorrhizal fungi have been found associated with plants as early as the Devonian (Remy et al., 1994; Taylor et al., 1995), and have been suggested to have been responsible for the colonization of the land by plants (Pirozynski and Malloch, 1975). Although plants have evolved dramatically in form since their initial move onto the land, the fungi appear to be morphologically stable. Devonian fungi bear a striking resemblance to modern forms, as do many others throughout the fossil record. The presence of arbuscules is regarded as evidence of a mutualistic relationship in arbuscular mycorrhizae (Harley and Smith, 1983), and have recently been demonstrated in the Lower Devonian (Taylor et al., 1995). The arbuscular structure has been conserved through time. Morton (1990b) suggested that this might be due in part to stabilizing selection of the symbiosis and to clonal reproduction that reduced the spread of changes. Arbuscular mycorrhizae, included in the order Glomales, are divided into two suborders: the Glomineae and the Gigasporineae. Although fossil representatives with affinities to the Glomineae are now known (Remy et al., 1994; Taylor et al., 1995), no fossil representatives of the Gigasporineae have been reported to date.

The Triassic of Antarctica is particularly rich in fungal remains. A trichomycetous fungus was described that shares many features with modern Eccrinales (White and Taylor, 1989b), and Palaeofibulus was reported as a basidiomycete based on clamp connections and spores (Osborn and Taylor, 1989). White and Taylor (1989a) described specimens of Endochaetophora and spores that resembled Endogone, the affinities of several spore types remain uncertain (White and Taylor, 1991). Spores comparable to Glomus suggesting affinities with mycorrhizal fungi have also come from these sites (White and Taylor, 1991). Spores like those of modern Sclerocystis have also been discovered, but some features make this assignment uncertain (Stubblefield et al., 1987a). Stubblefield et al. (1987b) also described a mycorrhiza that was attributed to Glomus. The fungus was found colonizing the roots of Antarcticycas (Smoot et al., 1985; Millay et al., 1987). The principal characteristics attributable to Glomus were the presence of vesicles and Glomalean arbuscules. However, a reexamination of this material reveals that Gigasporinean ar- 


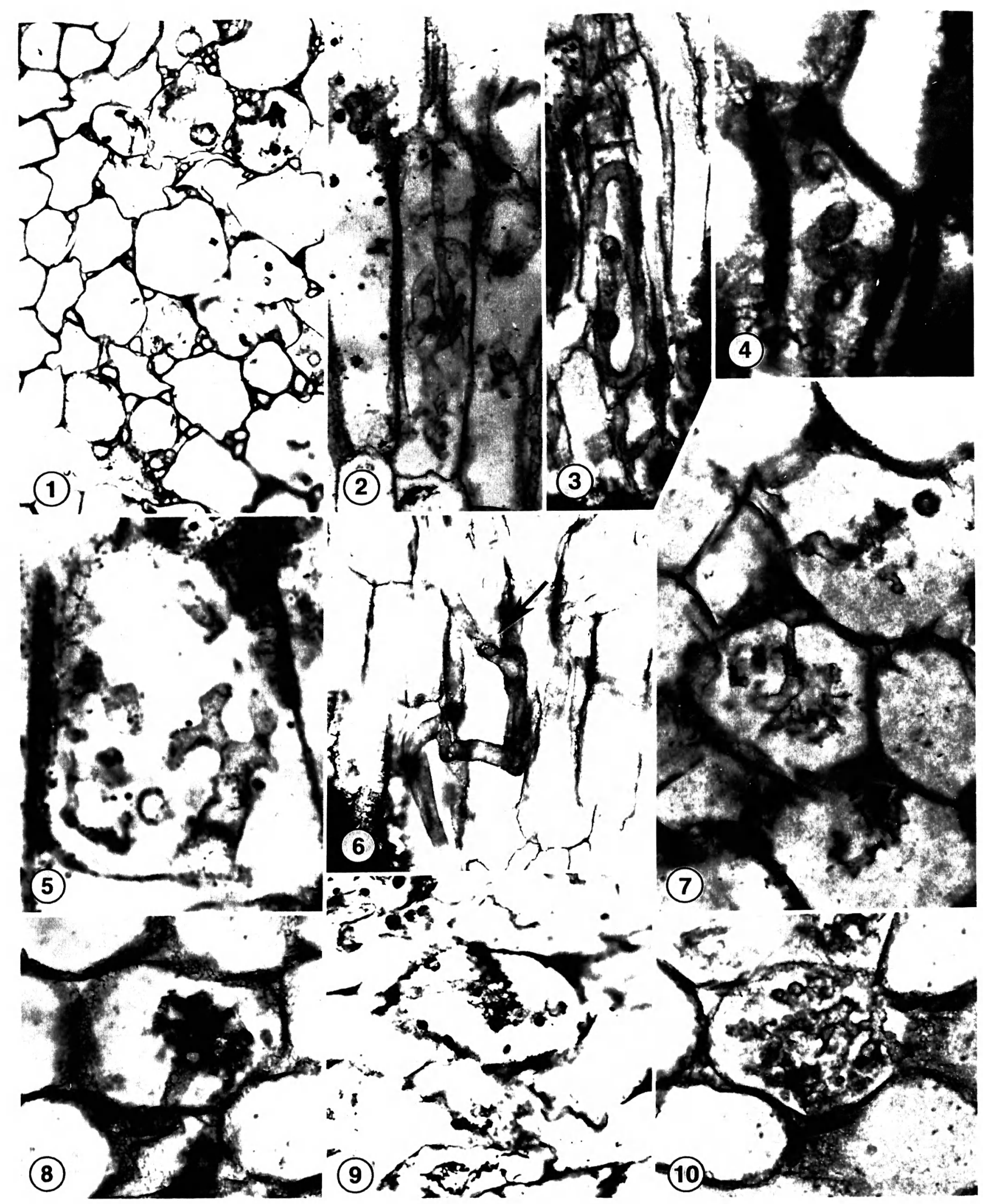

FIGs. 1-10. Gigasporites and Glomites mycorrhizae. 1. Cross section through root with intercellular and intracellular hyphae. Slide $16805, \times 400$. 2. Hyphae of Gi. myriamyces. Note the uneven thickness. Slide $16805 \times 400$. 3. Gi. myriamyces hypha with swelling. Slide 19748, $\times 400$. 4. Hypha of Gi. myriamyces, showing extensive coiling within the cell. Slide 19741, $\times 880$. 5. Dichotomously branched hypha. Note septum at branching point. Slide $16805, \times 640$. 6 . Hypha with discontinuous 
buscules and hyphae also occur with those allied with Glomus. These mycorrhizae actually comprise both suborders of the Glomales and exist as a mixed colony, a situation that is quite common today (e.g., Brundrett and Kendrick, 1990) but has previously been unreported in the fossil record. It is the intent of this paper to describe and illustrate examples of mycorrhizal fungi of the two types found in the roots of Antarcticycas, one of which represents the first occurrence of a member of the Gigasporineae reported from the fossil record.

\section{MATERIALS AND METHODS}

The specimens are contained in siliceous chert collected from the Fremouw Formation in the Beardmore Glacier region of Antarctica by the late James Schopf and others (see Smoot et al., 1985), and are regarded as early Middle Triassic in age (Farabee et al., 1990). Cellulose acetate peels were made following etching with hydrofluoric acid, and microscope slides prepared from selected peels. The specimens are housed in the University of Kansas paleobotanical collection under the aquisition numbers 13,43113,$484 ; 16,722-16,815$, and 19,739-19,759.

\section{RESULTS}

Two types of mycorrhizae are found evenly distributed throughout the cortex of Antarcticycas roots and consist of arbuscules, vesicles, and hyphae (FIG. 1). Some roots lack mycorrhizae, but when fungi are present, the colonization rate is high. Two types of fungi are present, one with affinities to the Gigasporineae and the other to the Glomineae. Both can occur in close association in the same root. Reproductive spores do not occur in the specimens or the surrounding matrix; therefore, the fungi cannot be identified as to modern genera. However, the fungi can be identified to the suborder level based on vegetative characteristics. They are described as form groups in order to document their presence in the Triassic and their affinities as closely as can be determined.

Gigasporites myriamyces Phipps et Taylor, formagen. et sp. nov.

Hyphae occupying inter- and intracellular cortical regions of roots, hyphae (3.8-) $6.9(-12) \mu \mathrm{m}$ in diameter, often forming loops and coils within cells; septa frequently present, branching dichotomous, occasionally trichotomous; arbuscules with thick trunks (3.7-) $6.3(-7.7) \mu \mathrm{m}$ in diameter, abrupt narrowing of branches, branching secondary, ultimate branches less than $1 \mu \mathrm{m}$ in diameter.

HOLOTYPE. Specimens on slide 19759 , Fig. 7 in this paper.

PARATYPES. Specimens on slides 16805 ; 16799 ; $19748 ; 13478$; 19746 , Fig. 2-10 in this paper.

Type slides are housed in the University of Kansas paleobotanical collection.

Collection locality. Fremouw Peak, Antarctica, near the Beardmore Glacier

Age. Early Middle Triassic

Stratigraphic position. Fremouw Formation, Beacon supergroup

Etymology. Gigasporites is used to designate its similarity to the family Gigasporaceae; the ending -ites is used to note its fossil status. The epithet myriamyces refers to the unknown number of biological species comprising this designation.

Gigasporites myriamyces hyphae and arbuscules are found evenly distributed throughout the cortex of the roots. Hyphae are inter- and intracellular (FIG. 1). Hyphae are irregular in thickness (FIG. 2), occasionally characterized by swollen areas (FIG. 3), and are extensively coiled within the cells (FIG. 4). Hyphae average $6.3 \mu \mathrm{m}$ in diameter, and branching is dichotomous (FIG. 5). Septa are common, particularly at branching points, but septa are not continuous throughout the diameter of the hypha (FIG. 6). One consistent feature of $G$. myriamyces is the absence of vesicles in association with hyphae.

Arbuscules are not confined to any distinct region of the cortex, and occur in various stages of deterioration. They occupy an average of $55 \%$ of the cell volume, with no observable size or shape differences for the cells containing arbuscules. The arbuscules of Gigasporites are robust and are characterized by thick trunks. Arbuscular branching is coarse (FIG. 7), and usually can be determined only to the second order of branching (FIG. 8,9). Several cortical cells appear to contain cross or slightly oblique sections of arbuscules at a low point of branching (FIG. 10). Only one arbuscule is present within a single cell.

Glomites cycestris Phipps et Taylor, sp. nov.

$\leftarrow$

septum (arrow). Slide 19746, $\times 450$. 7. Gi. myriamyces arbuscule. Slide 19759, $\times 600$. 8. Gi. myriamyces arbuscule. Slide $13478, \times 480$. 9. Gi. myriamyces arbuscule. Slide $16812, \times 500$. 10. Cross section through arbuscule of Gi. myriamyces. Slide $13478, \times 500$. 
Hyphae (1.6-) $5.3(-7.4) \mu \mathrm{m}$ in diameter, interand intracellular, occasionally sinuous, septa frequent, branching dichotomous; arbuscules with trunks (1.6-) $2.5(-4.0) \mu \mathrm{m}$ in diameter, branching secondary, ultimate branches less than $1 \mu \mathrm{m}$ in diameter; vesicles (8-) $33(-56) \mu \mathrm{m}$ in diameter, lateral and terminal, occasional septum present at base.

HOLOTYPE. Specimens on slide 19754, Figs. 1113 in this paper.

PARATYPES. Specimens on slides 16805,16812 ; $13450 ; 13479 ; 19742,19759$, FIG. 11-18 in this paper. Type specimens are housed in the University of Kansas paleobotanical collection.

Collection locality. Fremouw Peak, Antarctica, near the Beardmore Glacier

Age. Early Middle Triassic

Stratigraphic position. Fremouw Formation, Beacon supergroup

Etymology. Glomites refers to similarities to the Glomineae (see Remy et al., 1994). The epithet cycestris comes from its location within (Greek-estris) a cycad.

There are several features that are common to both $G i$. myriamyces and $G$. cycestris. Hyphae are interand intracellular, as in Gi. myriamyces, also with typically dichotomous branching and noncontinuous septa near branching points. Arbuscules of both types are not confined to any distinct region of the cortex, and are found in various stages of deterioration. Each cell contains a single arbuscule, although two arbuscules can branch off of the same hypha into adjacent cells (FIG. 11).

Although Glomites hyphae fall within the same size range as those attributed to Gigasporites, they are generally smaller on average at $5.3 \mu \mathrm{m}$. This is due in part to the absence of irregular thickenings in the hyphae. Hyphae are straight, coiling only gradually if at all, are uniform in thickness (FIG. 12), and have $\mathrm{h}$ shaped junctions (FIG. 13). These hyphae are associated with both arbuscules and vesicles. Arbuscules of Glomites have thin trunks and a fine branching pattern that narrows gradually from order to order (FIGS. 14, 15). Vesicles are associated with hyphae and arbuscules, and range from $8 \mu \mathrm{m}$ to $56 \mu \mathrm{m}$, averaging $33 \mu \mathrm{m}$ in diameter. We believe that the wide variation in vesicle size could be the result of differing stages of development of the vesicles. Some vesicles are represented simply as small swellings on the hyphae while others occupy most of the cell volume. Antarcticycas root cells containing vesicles are the same size as other cortical cells. Vesicles occur more frequently in a lateral position than terminal; septa are occasionally present, appearing in both types in approximately equal frequencies (FIGS. 16-18). Most appear ovoid in shape; however, a few are elliptical or otherwise irregularly shaped. Various other spores are present in the roots, but are not associated with either species (FIG. 19). One structure appears to be a spore and hypha within another spore (FIG. 20). AM fungi are known to produce spores within spores of other AM species (Koske, 1984). In addition, Glomus species can form spores by internal proliferation, that is caused by a hypha growing into a spore of the same individual and forming a new spore (Koske, 1985). This situation is superficially most similar to the structure in FIG. 20, although the size and placement seems to preclude it from being a spore. Nonetheless, the similarities raise the possibility that it is a propagative structure from one of the mycorrhizae.

\section{DISCUSSION}

The mycorrhizae in Antarcticycas were described as Glomus-like due to the presence of vesicles, as only members of the Glomineae produce vesicles (Stubblefield et al., 1987b). However, there is a definite dimorphism regarding the morphology of the hyphae and arbuscules found in Antarcticycas which reveals that both subgroups are represented in the roots. It is common for several species of endomycorrhizae from different families to be present within the same root, even closely associated in the same area (e.g., Abbott and Robson, 1984; Brundrett, 1991).

The roots of cycads are generally known for their relationships with cyanobacteria, that form nodules on the roots, rather than with endomycorrhizae. Many studies have focused on the cyanobacteria and make no mention of the presence of endomycorrhizae (e.g., Grobbelaar et al., 1987; Ahern and Staff, 1994). Interestingly, a summary of plant families containing mycorrhizal symbionts does not even include members of the Cycadales (Newman and Reddell, 1987). Fungi previously reported in the root nodules were suggested to assist in the creation of air spaces for cyanobacterial colonization (Pant, 1973). The identity of the fungus was not determined, and the digestion of cortical cells seems to be the function of a saprophytic fungus rather than a mycorrhizal one. However, more recent studies have identified many species of arbuscular mycorrhizae colonizing roots of Cycas circinalis, including species of Glomus and Gigaspora (Iqbal and Shahbaz, 1990). This shows that at least some modern cycads, while incorporating cyanobacteria, still maintain a relationship with arbuscular mycorrhizae.

The taxonomy of arbuscular mycorrhizal fungi has been extensively modified from their original inclusion within the Endogonaceae (Gerdemann and Trappe, 1974). Currently, the order Glomales in- 


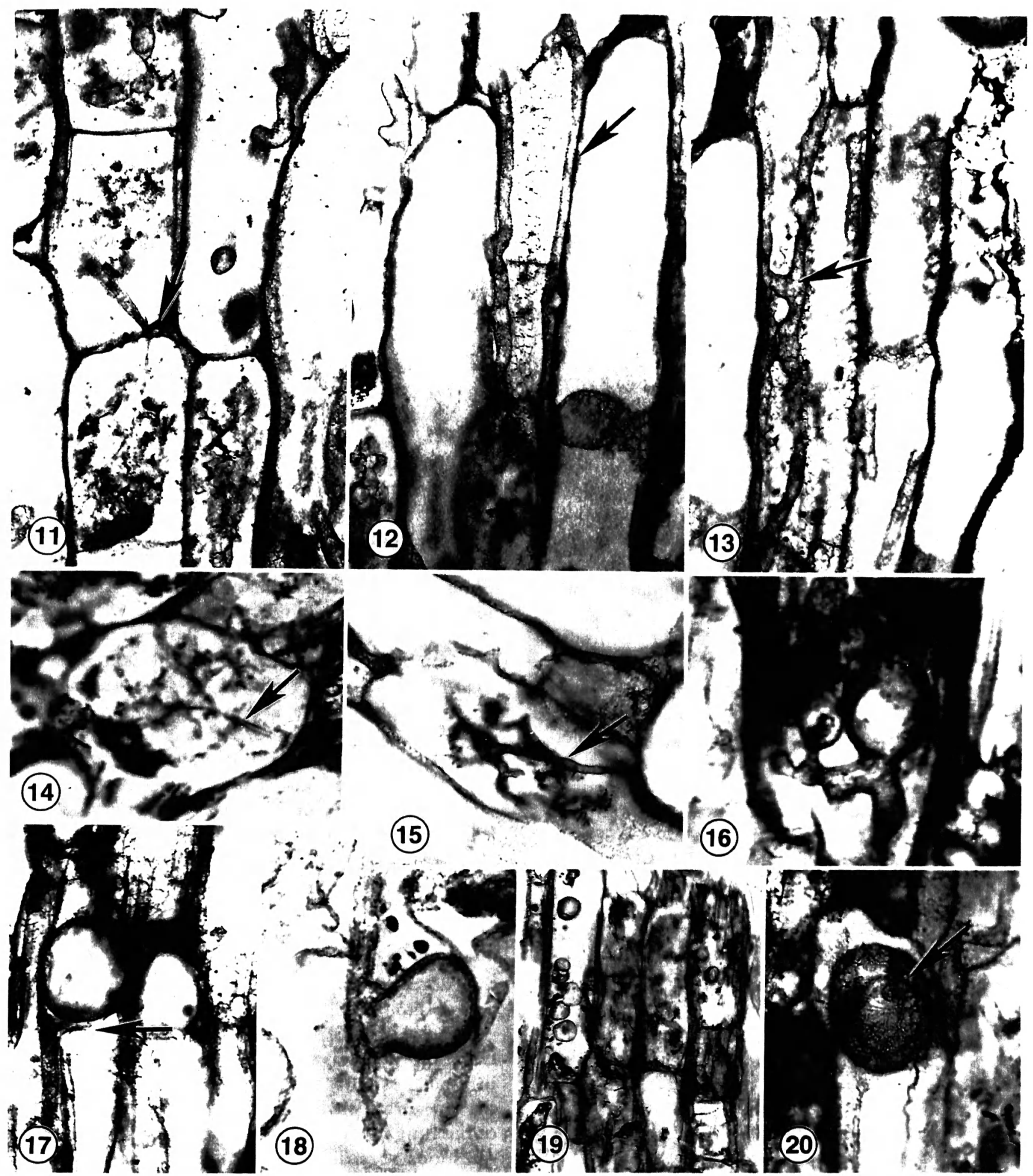

FIGs. 11-20. Glomites and miscellaneous mycorrhizae. 11. G. cycestris arbuscules, both originating from one point (arrow). Slide $19754, \times 500$. 12. Hyphae of $G$. cycestris (arrow). Slide $19754, \times 500.13$. Hyphae of $G$. cycestris connected by h junctions (arrow). Slide $19754, \times 500.14$. Arbuscule of $G$. cycestris, arrow at trunk. Slide $13450, \times 625.15$. G. cycestris arbuscule, slide $13459, \times 500$. 16. Lateral vesicle of $G$. cycestris, without septum. Slide $19745, \times 1000$. 17. Terminal vesicle of $G$. cycestris, with septum (arrow). Slide 19742, $\times 400.18$. Lateral vesicle of $G$. cycestris, with septum. Slide $590 \mathrm{~B}$ bot $3 \mathrm{a}, \times 400$. 19. Various spores within Antarcticycas roots. Slide $16804, \times 200$. 20. Unidentified spore within a spore (arrow). Slide $13478, \times 500$. 
cludes two suborders, the Glomineae and Gigasporineae. The suborder Glomineae is comprised of the families Glomaceae, with the genera Glomus and Sclerocystis, and Acaulosporaceae, with the genera Acaulospora and Enterophspora. The suborder Gigasporineae contains the family Gigasporaceae, with the genera Gigaspora and Scutellospora. This classification was proposed by Pirozynski and Dalpé (1989), and refined by Morton and Benny (1990). The separation of: families and genera are based on spore characters, including the number and type of spore walls, the attachment of the spore to its subtending hypha, and the mode of spore germination (Morton and Benny, 1990). Fatty acid methyl ester profiles have also been found to be taxonomically significant from the species to the family level (Morton and Bentivenga, 1994). Separation of the two fossil mycorrhizae below the level of suborder is difficult given the nature of the specimens, as neither of these can be documented in the fossil specimens. Spores that do occur in the fossil roots are not similar to any spores in the Glomales, nor are they physically connected to the mycorrhizae. Moreover, they have been suggested to be spores of a saprophyte (Stubblefield et al., 1987b).

Vegetative characters have been found to be useful in identifying mycorrhizae to the suborder, and occasionally to the family level. Originally, Gallaud (1905) separated mycorrhizae that formed intercellular hyphae (Arum series) from those that formed intracellular hyphae (Paris series). It was later demonstrated that the same mycorrhiza could produce both series depending on the host (Gerdemann, 1965). Other characters of the hyphae have been shown to be stable. Glominean hyphae are characterized by long parallel strands, connected by " $h$ " junctions, while Gigasporinean hyphae are coiled and irregularly swollen, with various knobs and projections (Morton and Bentivenga, 1994). Glominean arbuscules narrow gradually in hyphal diameter, and are finely branched at the tips (Brundrett and Kendrick, 1990). Within the Gigasporineae, arbuscules narrow abruptly from the trunk to the branches, resulting in less branching and more coarse arbuscules (Brundrett and Kendrick, 1990). With reference to family characters, vesicles in the Glominean families differ in shape. The Glomaceae have vesicles that are elliptical, while those in the Acaulosporaceae are knobby and irregular (Morton and Bentivenga, 1994; Morton and Benny, 1990). However, vesicles within the fossils span the ranges of both. Infection pattern characteristics of the hyphae were suggested to be relatively stable and distinct for the different genera even before the current classification scheme was proposed, and a preliminary key was made to distin- guish genera from these characteristics (Abbott, 1982). Using this key, G. cycestris and Gi. myriamyces keyed out closest to Glomus and Gigaspora respectively, but Abbott and Robson (1978) cautioned that the usefulness of this key was limited because the stability of generic morphology might break down under different environmental conditions, different hosts, or different nutrient levels. The name Glomites cycestris is used to refer to the suborder affinity with the knowledge that the specimens may encompass several species attributed to either or both families in the suborder. The Gigasporineae contains only one family, Gigasporaceae, so the Gigasporinean mycorrhiza present can be determined at the family level of Gigasporaceae. The name Gigasporites myriamyces may also encompass several biological species, and may include representatives of both Gigaspora and Scutellospora, that cannot be distinguished based on only hyphal and arbuscular features. Nonetheless, these specimens are being grouped under the generic name Gigasporites to indicate the family affinity and the fossil nature of the specimens. Although it is difficult to distinguish families in these specimens, the evidence for both suborders is clear and provides important evolutionary information about the Glomales.

Morton (1990b) suggested that the sexual stage in Gigaspora species was advanced, and therefore the Gigasporinean lineage appeared later than the Glominean. This hypothesis could not be supported by any fossil data at the time, as no fossil representatives of the Gigasporineae had been described. Glomus-like fungi are known from the Devonian (Taylor et al., 1995; Remy et al., 1994), and possibly from the Silurian, but the Silurian material has not been conclusively identified (Pirozynski and Dalpé, 1989). A ribosomal DNA study suggests the origin of endomycorrhizae as being between 462 and 353 mya (Simon et al., 1993). These data also suggest that the split of: the Glominae and Gigasporinae occurred at least 250 mya (Simon et al., 1993). However, this analysis also separated Acaulosporaceae from the Glomaceae as being more closely related to the Gigasporaceae, raising the possibility that the results do not reflect entirely accurate phylogenies. More recently, analyses of other fungal components have brought about more questions regarding the evolutionary history of the Glomales. An analysis of cell wall glucans in the Glomales supported the separation of the Glomineae and the Gigasporineae, but suggested that the Gigasporineae was more closely allied with some members of the Zygomycetes than was the Glomineae (Gianinazzi-Pearson et al., 1994). This casts doubt on the idea of the Gigasporineae branching off of the Glomineae (Morton, 1990a), but supports earlier conten- 
tions (Pirozynski and Malloch, 1975; Pirozynski and Dalpé, 1989) that at least some of the Glomales might not belong in the Zygomycotina. Further work is needed in all areas of comparison in terms of adding more characters and in comparing them to other taxa to better resolve the phylogenetic relationships that exist in the Glomales.

The infection pattern of the hyphae and the distribution of the arbuscules within the cortex of the fossil roots are characteristics that provide information about the evolution of the mycorrhizae. Specimens of Glomites from the Devonian form arbuscules in a very restricted zone of cells near the perimeter of the axis (Taylor et al., 1995) of Aglaophyton, although they occur throughout the axes of other Devonian plants (Hass, pers. comm.). In the Triassic, Glominean mycorrhizae form arbuscules throughout the cortex of the roots. Presumably the Gigasporinean mycorrhiza in the Triassic is at an early evolutionary stage based on estimates of the inception of the suborder. However, the fungus is found throughout the cortex with an infection rate as high as the Glominean mycorrhiza. This suggests that perhaps it was able to adapt to its host environment more quickly than the Glominean mycorrhizae.

The presence of Gigasporites myriamyces in the Triassic, in a mixed colony with members of the Glomineae, supports the molecular evidence of the antiquity of the Gigasporinean lineage, providing it with a minimum age of early Triassic, and indicates that complex mycorrhizal relationships developed concurrently with the evolution of the Gigasporineae. These specimens both provide a reference for, and assist greatly in, the elucidation of the evolutionary relationships of the mycorrhizas to each other and to the plants that they inhabited.

\section{ACKNOWLEDGMENTS}

This work was supported in part by the National Science Foundation (OPP-9315353). We are grateful to Dr. Joseph Morton for his invaluable assistance and for access to the INVAM collection.

\section{LITERATURE CITED}

Abbott, L. K. 1982. Comparative anatomy of vesicular-arbuscular mycorrhizae as formed on subterranean clover. Aust. J. Bot. 30: 485-499.

$\longrightarrow$, and A. D. Robson. 1978. Growth of subterranean clover in relation to the formation of endomycorrhizas by introduced and indigenous fungi in a field soil. New Phytol. 81: 575-585.

$\longrightarrow$, and 1984. Colonization of the root system of subterrranean clover by three species of vesicularmycorrhizal fungi. New Phytol. 96: 275-281.
Ahern, C. P. and I. A. Staff. 1994. Symbiosis in cycads: the origin and development of coralloid roots in Macrozamia communis (Cycadaceae). Amer. J. Bot. 81: 15591570.

Brundrett, M. 1991. Mycorrhizas in natural ecosystems. Adv. Ecol. Res. 21: 171-313.

$\longrightarrow$, and B. Kendrick. 1990. The roots and mycorrhizas of herbaceous woodland plants II. Structural aspects of morphology. New Phytol. 114: 469-479.

Farabee, M. J., E. L. Taylor and T. N. Taylor. 1990. Correlation of Permian and Triassic palynomorph assemblages from the central Transantarctic Mountains, Antarctica. Rev. Palaeobot. Palynol. 65: 257-265.

Gallaud, I. 1905. Études sur les mycorrhizes endophytes. Rev. Gén. Bot. 17: 5-48, 123-136, 223-239, 313-325, 425-433, 479-500.

Gerdemann, J. W. 1965. Vesicular-arbuscular mycorrhizae of maize and tuliptree by Endogone fasciculata. Mycologia 57: 562-575.

$\longrightarrow$, and J. M. Trappe. 1974. Endogonaceae in the Pacific Northwest. Mycologia Memoirs 5: 1-76.

Gianinazzi-Pearson, V., M-C. Lemoine, C. Arnould, A. Gollotte, and J. B. Morton. 1994. Localization of $\beta$ (1-3) glucans in spore and hyphal walls of fungi in the Glomales. Mycologia 86: 478-485.

Grobbelaar, N., W. E. Scott, W. Hattingh, and J. Marshall. 1987. The identification of the coralloid root endophytes of the Southern African cycads and the ability of the isolates to fix dinitrogen. S. Afr. J. Bot. 53: 111-118.

Harley, J. L. and S. E. Smith. 1983. Mycorrhizal Symbiosis. Academic Press, London/New York. 483 pp.

Iqbal, S. H. and Shahbaz. 1990. Influence of aging of Cycas circinalis on its vesicular-arbuscular mycorrhiza and endogonaceous spores in the rhizosphere. Trans. Mycol. Soc. Japan 31: 197-206.

Koske, R. E. 1984. Spores of VAM fungi inside spores of VAM fungi. Mycologia 76: 853-862.

- 1985. Glomus aggregatum emended: a distinct taxon in the Glomus fasciculatum complex. Mycologia 77: 619-630.

Millay, M. A., T. N. Taylor, and E. L. Taylor. 1987. Phi thickenings in fossil seed plants from Antarctica. IAWA Bulletin n. s. 8: 191-201.

Morton, J. B. 1990a. Evolutionary relationships among arbuscular mycorrhizal fungi in the Endogonaceae. Mycologia 82: 192-207.

1990b. Species and clones of arbuscular mycorrhizal fungi (Glomales, Zygomycetes): Their role in macro- and microevolutionary processes. Mycotaxon 37: 493-515.

arbuscular mycorrhizal fungi (Zygomycetes): A new order, Glomales, two new suborders, Glomineae and Gigasporineae, and two new families, Acaulosopaceae and Gigasporaceae, with an emendation of Glomaceae. Mycotaxon 37: 471-491.

endomycorrhizal fungi (Glomales, Zygomycetes) and their role in defining taxonomic and non-taxonomic groups. Plant and Soil 159: 47-59. 
Newman, E. I. and P. Reddell. 1987. The distribution of mycorrhizas among families of vascular plants. New Phytol 106: 745-751.

Osborn, J. M. and T. N. Taylor. 1989. Palaeofibulus gen. nov, a clamp-bearing fungus from the Triassic of Antarctica. Mycologia 81: 622-626.

Pant, D. D. 1973. Cycas and the Cycadales. Certral Book Depot, Allahabad. 255 pp.

Pirozynski, K. A. and Y. Dalpé. 1989. Geological history of the Glomaceae with particular reference to mycorrhizal symbiosis. Symbiosis 7: 1-36.

- and D. Malloch. 1975. The origin of land plants: a matter of mycotropism. BioSystems 6: 153-164.

Remy, W., T. N. Taylor, H. Hass, and H. Kerp. 1994. Four hundred million year old vesicular arbuscular mycorrhizae. Proc. Natl. Acad. Sci. 91: 11841-11843.

Simon, L., J. Bousquet, R. C. Lévesque, and M. Lalonde. 1993. Origin and diversification of endomycorrhizal fungi and coincidence with vascular land plants. Nature 363: $67-69$.
Smoot, E. L, T. N. Taylor, and T. Delevoryas. 1985. Structurally preserved fossil plants from Antarctica. I. Antarcticycas, gen. nov., a Triassic cycad stem from the Beardmore glacier area. Amer. J. Bot. 72: 1410-1423.

Stubblefield, S. P., T. N. Taylor, and R. L. Seymour. 1987a. A possible endogonaceous fungus from the Triassic of Antarctica. Mycologia 79: 905-906.

,-- , and J. M. Trappe. 1987b. Vesicular-arbuscular mycorrhizae from the Triassic of Antarctica. Amer. J. Bot. 74: 1904-1911.

Taylor, T. N., W. Remy, H. Hass, and H. Kerp. 1995. Fossil arbuscular mycorrhizae from the Early Devonian. Mycologia 87: 560-573.

White, J. F. Jr. and T. N. Taylor. 1989a. Triassic fungi with suggested affinities to the Endogonales (Zygomycotina). Rev. Palaeobot. Palynol. 61: 53-61. , and - 1989b. A Trichomycete-like fossil from the Triassic of Antarctica. Mycologia 81: 643-646. , and - 1991. Fungal sporocarps from Triassic peat deposits in Antarctica. Rev. Palaeobot. Palynol. 67: 229-236. 